logos_i_ethos_2019_special issue,pp.155-174

DOI: http://dx.doi.org/10.15633/lie.3473

Bartosz Jastrzębski

ORCID: https://orcid.org/0000-0002-5904-3000

\title{
Henryk Rzewuski - on the way to Polish national philosophy
}

"For that which only follows from logical deductions, methods devised for thought, and disquisitions will only be a theory that at best can serve as a wit's plaything, but will never turn into anything vital. Life is inspiration, but reasoning is not, and what is more, it is indeed an obstacle to inspiration."

(Henryk Rzewuski)

The general public know Henryk Rzewuski primarily as a writer, author of novels and tales of the gentry, particularly of the greatly popular Pamiatki JPana Soplicy, cześnika parnawskiego, ${ }^{2}$ which is a literary monument to the mentality and customs of the 18thcentury, or more broadly, OldPolish gentry. The above-mentioned Pamiatki made a great impression on the contemporary audience, the delighted ones including Adam

Bartosz Jastrzębski - a doctor of philosophy with a habilitation degree, an ethicist, a lecturer at the Institute of Journalism and Social Communication at the University of Wrocław. He specialises in the borderlands of philosophy, anthropology and literature, as well as history, memory, spiritual and religious investigations. He tracks leitmotifs of the everyday, its torments and little hopes, on which he has written three volumes of essays: Pają. Szkice prawie filozoficzne (2007), Próżniowy świat (2008) oraz Wędrówki po codzienności. Eseje o paru ważnych rzeczach (2011). Currently, he mainly specialises in concepts of conservative philosophy. Mickiewicz himself. As a unique record of the Sarmatian concept of life presenting a nostalgically colourful, but also irretrievably obsolescent

1 H. Rzewuski, Wędrówki umysłowe. Mieszaniny obyczajowe, Kraków 2010, p. 140.

2 H. Rzewuski, Pamiątki J. Pana Seweryna Soplicy, cześnika parnawskiego, Lwów $1852^{3}$. 
world of the Polish court and its noble identity, the work was almost elevated to a cult status. The enthusiasm for the author and his works vanished immediately and completely when in 1841 he published another book - Mieszaniny obyczajowe przez Jarosza Bejłe. ${ }^{3}$ The readers were so shocked that Rzewuski assumed the odium of a renegade and recreant, almost a traitor to the national cause. What made the indignation immediately rise to such heights that but a short while before had been reached by enthusiasm?

\section{A conservative or a traitor to the national cause?}

This turn will not be that surprising any more if we imagine that the readers, embattled and humiliated by a lack of self-containment and insurgent defeats, could find in the said volume the following thoughts and advice:

We who by the act of Divine Providence have become a part of the powerful Russian association, let us bring our provincial wares to the general, shared treasury, and united with our countrymen, let us confirm one another in the conviction that the Russian literature, which flourishes in such vast spaces [...] should display Ukrainian, Muscovite, Severian, Volgaic, Donian, Volhynian, Lithuanian and even Siberian elements... ${ }^{4}$

He confirmed, elaborated and enriched these pan-Slavic fantasies, at least in his private writings, with specific and even more disturbing declarations: "By no means do I conceal that I am Russian by honour and duty, which for a representative of the gentry and a Christian is stronger than all sympathies that I do not intend to renounce. I took the oath and until I am released from it by my lord I will abide by it." ${ }^{5}$

${ }^{3}$ H. Rzewuski, Mieszanimy obyczajowe przez Jarosza Bejłe, vol. 1, Wilno 1841.

${ }^{4}$ H. Rzewuski, Mieszanimy obyczajowe przez Jarosza Bejłe, vol. 1, op. cit., p. 235.

5 As cited in: I. Węgrzyn, Henryk Rzewuski wobec Rosji i idei słowiańskiej, [in:] Między realizmem a apostazją narodową. Koncepcje prorosyjskie w polskiej myśli politycznej, Kraków 2015, p. 75. 
Such declarations, which were numerous and expressed completely openly and sometimes in an overtly provocative manner, were to be found in Count Rzewuski's writings. The psychological effect that they produced, and by extension the social reception of the count and his writings were easy to predict - the judgement was as harsh as possible. By way of illustration, let us mention an opinion by Stanisław Tarnowski, an attentive observer and reader living in the same era, though a much younger man (compared to others, his opinion should be seen as a toneddown one):

Mieszaniny caused a great deal of indignation with the author - as the Cracowbased conservative confirms - and the indignation never subsided, because the author purposely fuelled it with new works. Was the indignation legitimate? Yes: the book is undeniably evil, malicious, and malicious in an evil manner, if not evilmeaning, because its conclusion - which although admittedly remains unformulated, can be clearly inferred from what the author claims - is that Poland is not only in a state of partitioning, but decomposition, that the soul has long left it, and the putrescent body can be neither healed nor resurrected, and there is nothing left to be done but to bury it. ${ }^{6}$

Bleak conclusions, the truculent and revealing tone of the narrative as well as the explicitness and determination of negative assessments of the Polish condition contained therein gave rise to accusations of a lack of writing honesty, stirring up the darkest defeatism, tarnishing the national dignity, dissenterism, and finally, outright collaboration and treason, all the more so because the author would gladly live in Petersburg, not feeling any revulsion at Russia, or at least Russian aristocrats and the tsar's power. ${ }^{7}$ There is no room here for in-depth

6 S. Tarnowski, Henryk Rzewuski. Z odczytów publicznych odbytych we Lwowie w roku 1887, Lwów 1887, p. 20.

7 In his short study about Rzewuski, Tomasz Merta invokes the following epigram believed to have been written by "general Morawski," and directed at Rzewuski: "Well, this Divinity, the motherland/ Is but a delusion/For when I rest in the cool shade of these trees/When this soil breeds a flower like it used to/ What do I care who treads this soil/ Or who rules the nation!/ All of a sudden 
deliberations on these accusations, which require a separate, wideranging and reliable study (and arguably it would still be very difficult to reach agreement in assessments). It is probably true that "he saw himself and his contemporaries as witnesses to the dying of Polishness, which now - having lost its statehood and in the face of the definitive end of the Sarmatian system of the gentry culture - is doomed to be conquered by the Russian Empire - the victorious form of the future civilisation." $\mathrm{He}$ may indeed have believed that "Poland brought its demise upon itself, because it defied its own being. Nations resemble organisms and just like them they may (need to?) die. And when that happens, nothing can be done about it." However, it would be erroneous to assume that these convictions were fully expressive of Rzewuski's attitude to the Polish cause - as we will see, it was more complex and highly ambivalent. However, at this point - given the prospect of the issues to be addressed in the subsequent sections of the present paper - let me just note that in my opinion Henryk Rzewuski's attitude towards the question of the Republic of Poland's sovereignty (as it was in the mid-19th century) was not a form of recreancy or national apostasy, but rather a logical consequence of a conservative philosophy - and the resultant moral and intellectual attitude - developed by the author of Mieszaniny obyczajowe; it is this philosophy that we are going to take a closer look at here. For we will be treating Rzewuski like a philosopher, and not a "Sunday" or casual philosopher for that matter, but like an author of coherent, complete and original thought (though not a "systema") which he contained - in its most condensed form - in Wędrówki umystowe przez autora Zamku Kaniowskiego (Petersburg 1851).

Therefore, as I mentioned before, Henryk Rzewuski was not a Russified national apostate, but we would rather say - to use the exceptionally appropriate and useful typology proposed by Adam Wielomski - that

a pig that was lying in a nearby puddle / Having heard the thing out/ Said: Good Sir/ My sentiments exactly" (T. Merta, Nieodzowność konserwatyzmu. Pisma wybrane, Warszawa 2012, pp. 242-243.

8 I. Węgrzyn, Henryk Rzewuski wobec Rosji..., op. cit., p. 80.

9 T. Merta, Nieodzowność konserwatyzmu..., op. cit., p. 242. 
he was a typical example of a "radical conservative." A conservative like this is characterised by a special attitude to the present whereby guided by the conviction that the true reality has died and can only be found in memories, he "backs out of the political struggle and into the metaphysical field, thus acknowledging the defeat in the empirical world. Pushed out of the world by utopian activists, he draws back and goes looking for shelter in the world of Platonic ideas. [...]. A radical conservative's views are marked by deep pessimism as to the future: things can only get worse, because the decomposition progresses day by day. Such conservatives like to write theoretical works about political philosophy and historiosophy to demonstrate the meaning of history: heading towards a downfall." ${ }^{\circ}$

And that is what Rzewuski did: he turned his back on the present to face the glorious, Sarmatian past of the Polish people, in order to save it by way of description - that is to reconstruct and conserve the Republic of Poland in spirit and imagination. It was only there that, in his opinion, such reconstruction was possible and advisable. The count did not let himself be Russified - he hardly ever mentions Russia and Russianness in his numerous writings. Despite the years he spent in Petersburg, he reportedly did not even speak good Russian, and he did not write in the language (in the literary sense) at all. It all goes to show that the tsars' empire as a cultural phenomenon held no interest for him. But it is true that Rzewuski was a conservative (and a radical one for that matter), and the essence of conservatism involves legitimism - the conviction that the royal authority comes from God, and the people are under no circumstances empowered to remove the monarch - and in the author's lifetime it was the Russian tsars who were, by the providence of the Most High, kings of Poland. Thus, it was to them that an honourable nobleman owed allegiance, especially in the face of the revolutionary ideas and movements coming in from the West. Given this context, Iwona Węgrzyn is right in observing that Rzewuski was an avowed conservative "who justified his unqualified legitimism with regard to the authority with

10 A. Wielomski, Prawica $w$ XX wieku, Radzymin 2013, pp. 27-28. 
the necessity to yield to the decrees of Providence and with the attempt at defending the remains of the gentry tradition against the plague of revolution approaching from the West." ${ }^{11}$ Underlying this view is the following firm conviction: if we renounce allegiance to kings, whose power after all always comes from God, the world will fall into decay and become plunged into anarchy and dark mists of bloody revolution. Hence, "society cannot for a single moment be left without some authority maintaining allegiance."12 The author of Wędrówki umystowe was an adherent to hierarchical society where estate affiliation and its specific ties and loyalties logically precede and are morally superior to the ones of the nation. The then conservative thought was a far cry from nationalism, associated by the aristocracy and the gentry primarily with the destructive "Jacobinism" of the mutinous French crowd itching to hang the high-born (which, let us not forget, was the plight of Seweryn Rzewuski, Henryk's grandfather and a Targowica confederate, of which Henryk was most probably aware). Therefore, to Rzewuski thinking in nationwide terms definitely smacked of plebeianism and subversiveness. Order must be based on religion, high culture following therefrom as well as the social dominance of the people of noble birth, and not on the impulsive and irrational ethnia with its vast reaches. There is no doubt that the national feeling is important and beautiful, and in the purely human order - the most beautiful and the most important, but it still does not stand at the top of the axiological pyramid. "There is undoubtedly one feeling aroused by God, which has always been the most powerful mainspring of human activity; that feeling is love for one's country. [...]. It can be abused, because apart from God nothing should act as a man's goal, but it is certain that we have no single mental capacity that would not be associated with love for the motherland" [emphasis - B. J.]. ${ }^{13}$ Therefore, the divine order and loyalty to the Divine laws, hierarchies and duties resulting therefrom have absolute primacy. In other words,

11 I. Węgrzyn, Henryk Rzewuski..., op. cit., p. 85.

12 H. Rzewuski, Cywilizacja i religia, ed. A. Wielomski, Biała Podlaska 2009, p. 43.

13 H. Rzewuski, Wędrówki umystowe..., op. cit., p. 119. 
maintaining the order of the "organic" social structure is a value of overriding importance - it is overriding because it is theological. In the count's time the pillars of the order founded on religion and on the religion-practising gentry could effectively be kept upright only by the last feudal lord in Europe - the Russian tsar. Such was the conviction held by Rzewuski.

\section{Futility of traditional philosophy}

In Pamiątki Soplicy Rzewuski reminisces about former Poland, out of which - following the decomposition of its "physical" and political body - all life seeped irretrievably. There is no doubt that Rzewuski loves Polishness, eulogises and worships it, but in the way you eulogise, love and worship the deeds of a deceased man, invoking his image, remembering his soul and missing him. Rzewuski is not a recreant; he is a mourner and a bard singing a song of a non-existent world, dishing out acrid judgements about the surrounding world, so distant from the ancient and yet still relevant - norms and ideals. Noteworthily enough, he is an inconsistent "mourner," because his writings contain some germ of a plan for Polishness - that is something that can and should be constructed in the future - viable at least in the spiritual realm. This is because the reminiscing should become a foundation for immortalisation of the Polish spirit, thanks to which Poland would be reborn in imagination, art and thought. In a sense, this will be "Poland of the dreams." It is possible to build the national philosophy - the Polish philosophy - in which the spirit of the lost motherland will manifest itself, come to know itself and will be saved, at least in the ideal, eternal reality derived from the Divinity, the one that nations are essentially descended from and in which they truly exist. Rzewuski's plan for a national philosophy is a plan of a broader scope. The philosopher's remarks might be useful to the Spanish, the French or the Russians, even though - perforce - national philosophies there will be radically different from the Polish one, because the spirit of these nations is different, as is their manifested moral idea. And the very term "philosophy" takes on a completely new meaning in 
this context. It is not only different from the classical approach, but it is even overtly opposed to it.

And so it seems appropriate to begin with Rzewuski's view on philosophy as traditionally construed in order to grasp the essence of his conception of its revived and proper - that is national - variant.

Henryk Rzewuski's attitude to the existing philosophical reflection in the form pursued in his lifetime was invariably highly critical, and he found the fascination with the German thought - which nevertheless was the crowning achievement of the classical, Greek paradigm of philosophy - to be particularly unbearable and harmful. And so the count complains as follows: "Nowadays people believe that philosophy is a science which can be acquired merely by means of perusal of the treatises by German dreamers, as if becoming acquainted with philosophical systems was philosophy itself. And that is why we do not have philosophy; but it was quite advanced at the time when no one thought of it as a separate science. After all, there is more true philosophy in the Statutes of Lithuania, in the writings of Piotr Skarga and Maksymilian Fredro than in all those weird and stodgy treatises and systemata which have been spilling over from Germany since Kant's time and till this day, and which are but philosophical blather." ${ }^{\prime 4}$

Philosophy thus construed, or "philosophical blather" that is expressed in the "systemata" devised after the German fashion gives rise to Rzewuski's sheer and visible exasperation, as he is convinced of its spiritual pointlessness and thought futility. The idealist systems of Fichte, Schelling and Hegel, which are not very lucid, and yet highly abstract, are in Rzewuski's opinion a kind of intellectual aberration, which additionally have become popular with flighty teenagers, infecting them with claptrap which is pseudo-intellectual to boot. A speculative, purely theoretical philosophy which is detached from some real and specific substratum - as it is intended to be universalist (supranational) - is a symptom of ageing and dying of the spirit, and not of its blossoming. Having been detached "from the ground," from a specific community, its

14 H. Rzewuski, Wędrówki umysłowe..., op. cit., p. 129. 
history, culture and language, thought lapses into senile dementia and cognitive impotence.

Philosophy, for which there is no practical use whatsoever; it has an innate aversion to action; it only appears in decrepit collective bodies, like gout in old men's worn-out bodies; it puts up barriers to inspiration which has exclusive capacity to rejuvenate the aged political body - let me tell you, however generous it may be with praise for itself, philosophy is only seemingly learned nothingness. ${ }^{15}$

Likewise, historiosophy (the crowning achievement of which was Hegel's evolutionary idealism), which was contemporary with Rzewuski, does not merit recognition.

The way it is lectured on or elucidated in various writings today, philosophy of history is a completely erroneous science, because it is based on a freely supposed paralogism. Having dreamed up existence of some spirit of humanity, it claims that the universal spirit manifests itself phenomenally in the history of nations viewed not as monads, but as particles of this universal whole. In its view, all these phenomena occur in the order testifying to the progress of the human race, the end of which being disappearance of all distinct nationalities in the bosom of universal humanity common to all. It is no use inferring all developments with utmost talent and most exquisite logic, if the first principle of the entire systema is a glaring falsehood. ${ }^{16}$

The author of Wędrówki umystowe rejects the Hegelian phenomenology along with its conviction about the objective progress of history striving after the self-consciousness of the Absolute Spirit, self-knowledge that will include and unite in its own identity all "that is different" - the totality of spiritual - that is rational - life of humanity. Also, Rzewuski firmly challenges the reality of the abstract idea of "humanity" as such, viewing this absolutising hypothesis allegedly derived from the the nature of the Hegelian Spirit as the same uniformising and totalising, and by extension,

15 H. Rzewuski, Wędrówki umysłowe..., op. cit., p. 229.

16 H. Rzewuski, Wędrówki umysłowe..., op. cit., p. 225. 
destructive thought movement which at the social level constitutes the essence of the Revolution. He fully identified with the view held by Count Joseph de Maistre, who said: "The Constitution of 1795, like all the previous ones, was drawn up for man. But there is no man whatsoever in the world. In my life I have seen Frenchmen, Italians, Russians, etc. Thanks to Montesquieu I even know that it is possible to be a Persian; however, as regards man, I have not met a single one in my life; if there is one, I know nothing about that." ${ }^{17}$ Hence, national differentiation and social inequality are equally natural, organic. Abstract uniformisation of estates as well as, by extension, nations plunges individuals into chaotic, formless darkness, where - just like in the Schellingian absolute - "all cows are black." Elimination of the hierarchical span annihilates social energy, which is released (and conveyed in the right direction) whenever lower estates respect, revere and emulate the nobler ones, thereby naturally perfecting themselves (which is quite the opposite of what is happening nowadays, when higher estates - the aristocracy of spiritual services, as regrettably there is no other, under threat of "autistic" confinement and exclusion is reduced to tastes, needs and modes of being that typify lower estates). In the a priori speculated-out society of "equality" energy dissipates - just like culture does - and social ideals are dictated by the most numerous, and thus the lowest and least developed strata, that is the so-called third estate. But the nation is not about a wavering and irrational will of the people, but about the metaphysical, Divine idea, most perfectly expressed by the few but fully-fledged and most selfconscious individuals.

\section{The nation as a Divine idea}

And thus - given the issues addressed here - we have come to the pivotal concept of nation which was developed, in large measure on the

17 As cited in: A. Wielomski, Konserwatyzm. Główne idee, nurty i postacie, Warszawa 2007, pp. $80-81$. 
pattern provided by de Maistre, and promoted by Rzewuski. And so the philosopher says:

Nations do not live according to the external shapes through which they manifest their being, but according to the idea that moves them. For political bodies the idea is that which the soul is for man; the moment the soul leaves the body, the form of the body begins to fall apart, which is what in the count's opinion in fact happened to the Republic of Poland - the national idea arose out of the Divine revelation and was conveyed by oral tradition. [emphasis - B. J.] Thus we can see that the original political form of nations was patriarchal and theocratic. ${ }^{18}$

Every nation is a development and manifestation of the Divine revelation, the Divine idea, that is a divine creation, an eternal soul, irreducible to any world-immanent factors or its actual political condition (or its "body"). In order to emphasise this transcendent character of the national idea, Rzewuski - again like the Savoyard count - expresses his conviction about the existence of the angels of nations: intermediate beings occupying (since "nature does not take leaps") the metaphysical space in the hierarchy between individual souls and the Angelic Thrones and God Himself. The theologically grounded hierarchy (described by Pseudo-Dionysius the Areopagite, and subsequently elaborated by Saint Thomas and the scholastics) must be observed, and for this reason Rzewuski invokes the "patriarchal and theocratic" model. And again: we can clearly see that he found the tsarist autocracy, rather than the "nature-defying" republican system, to be a better match for this model. Viewed from the outside, a nation is indeed a collection of individuals, and to be precise - families. But internally, it is a spiritual being with a specific internal structure and stratification. As an incorporeal being, it lives even after the death of the geopolitical "body" - i.e. the state. Let us quote this extremely interesting passage about the angels of the nation in its entirety:

18 H. Rzewuski, Wędrówki umysłowe..., op. cit., p. 97. 
A nation in its corporeality, that is in that through which it manifests itself externally, arises either out of one family or an aggregation of various families. But that which constitutes its spirituality, that is life, must necessarily be somehow affected by God's breath. [...] Every nationality is a Divine revelation which comes to be fulfilled in time, irrespective of the creeds espoused by the individuals who make up nations [emphasis - B. J.]. In the Holy Scriptures, in the Book of Daniel, we can read that the angel of the Assyrians met the angel of the Persians - from this follows an obvious conclusion whereby a nationality, as revealed by the Divine power, could not survive in its pristine condition if it were not entrusted to the care of angels, the ministers of God in the earthly order. Every aggregation of diverse particles united into a single entity would immediately become decoupled if it were deserted by its angel; a mother country is a united aggregation operating in an angel's care. He provides the citizens with holy instincts for the prosperity of the country; he enlightens the shepherds of the people; he lifts the national prayers up to the feet of the Most High; he revokes well-deserved punishments for their transgressions; more often than not he salvages nations from the bottomless depths. And if crimes, and especially ones of a certain kind, have surged in the social body, if the nation, having scorned His constant inspiration, not only refuses to cooperate with God, but even impudently turns its back on Him, then the spirit of the nation - deserted by its angel and having lost that which supported its life - dies, and its place is for a few moments taken by some negative egoism and then the dead body begins to decay. ${ }^{19}$

And thus angels guard nations, which through their agency communicate with the Supreme Being. Every nation is characterised by its irreducible specificity, or what one might want to refer to as essence or even personality. The reason for its existence is exactly the revelation of this personality and its realisation in the earthly order. Like the multitude of mutually irreducible individual souls is a manifestation of the wealth of the Divine Plenitude (their unification being a crime against creation), the same can be rightly said about the souls of nations. They have their own characters and specific purposes in earthly existence: 
Every nation is a revelation of some moral idea to which its being is attached. It lives as long as it represents it - when it stops expressing it practically, it needs to die, because changing its calling does not lie in its power, as every moral idea is given by God. Deniers of God, who are, however, well versed in human matters, admit that nations are incarnated ideas expressed by the collection of families who unite the ideas into an organic whole. There is no other way to comprehend history. In that it is a nation, a nation needs to fulfil its calling, i.e., it needs to practically actualise the idea the representation of which was entrusted to the nation by God. ${ }^{20}$

How can this calling be recognised? According to the author of Mieszaniny obyczajowe it is revealed and advised on by a given nation's history, in which the calling reveals itself, at least to sound and attentive intuition capable of identifying it in the nation's tales. Among others, the kind of tales that the count collected in Pamiatki Soplicy. ${ }^{21}$ In his opinion, Polishness is realised in history (which in this sense constitutes a peculiar "phenomenology of the Polish spirit," a record of its "incarnation" and march through the inter-worldly life) and in historical institutions and customs - and not in contact with nature. Therefore, he who wants to see the essence of Polishness needs to embrace the vicissitudes of national history with a single glance:

No nation can renounce its past. Its present being and its future must necessarily be the outcomes of its past, and the sequence of moments following precisely one from another not only constitutes its history but is also its life. In a single man, every

20 H. Rzewuski, Wędrówki umysłowe..., op. cit., p. 241.

21 As Rzewuski notes, within the Polish national idea there is no place for any mysticism of nature: "For gazing at nature - he explains - has always been alien to the national genius of Poland. Beautiful views, chirping of wild birds, the varicolouredness of flowers of its land - in a word, all the poetry of nature has always been a letter closed to the Polish mind. To him, a brook has never been anything more than a place to build a mill; a wild bird, a question whether it is worth a bullet; flowers, a question whether they would make good hay for his steeds; a horse, his favourite animal, whether its back is good and legs are reliable. Even when he lived in Ruthenia, the poetry of nature, which so profusely spread all over the district, could not come to life in him. This can be observed in the homesteads belonging to the owners of Ruthenian hamlets; they were always situated in the bleakest place in the hamlet" (H. Rzewuski, Wędrówki umysłowe..., op. cit., p. 28). 
moment in which his life has already matured, that is he has the use of developed mental and organic capabilities, can only be an outcome of the course of this life. A mature age is a logical consequence of childhood and adolescence, and manifests itself according to the well-established order determined by the Creator. [...] It is to this destiny that a nation, or a collective man, is subject. It needs to - like the individuals it is composed of - follow the course of its life, in a no less logical order. ${ }^{22}$

\section{What is the Polish national philosophy supposed to be?}

Thus, the nation, as a "collective man," is not only subject to the natural, "biological" cycle of youth-maturity-old age and death, but also to the destiny that it can by no means evade - after all God is the master of History. This destiny is a temporal development of the eternal archetype which keeps manifesting itself in the specific matter of historical events. This goes on happening until the vital - physical and spiritual - forces of the nation desert it wholly, which presages its imminent death, at least in the world subject to the reign of time. Since it is in history that the idea of the nation reveals itself, the history is the only appropriate material for philosophical inquiry and investigations - all philosophy is therefore out of necessity philosophy of history and there is no and there can be no other true philosophy.

A nation's reasoning is always a fact - hence the history of every nation is its philosophy [emphasis - B. J.] - and the latter one is in some respect so constant in reviving the same facts that one poet-philosopher, a poet-prophet of our times, noted that the real history of one era of the nation is a symbol of its history in the subsequent eras. ${ }^{23}$

As long as it lives, the nation, even subconsciously, every now and then will try and realise its idea, the prototype of its being devised by God, which may unfortunately result in analogous occurrences in

22 H. Rzewuski, Wędrówki umysłowe..., op. cit., p. 237.

${ }^{23}$ H. Rzewuski, Wędrówki umysłowe..., op. cit., pp. 193-194. 
history. (It only remains to be hoped that this cyclicity is not literal or unavoidable - it would be terrible to know that the Republic will again have to suffer its dismal collapses).

Thus, a philosopher is a "self-consciousness" of the nation, because he is the one who captures the idea and presents it to the society - the nation acts, but lacks self-discovery. That is why the Statutes of Lithuania and the sermons of Piotr Skarga are philosophy: they express and objectivise the moral idea of the gentry nation of the Republic, reveal its essence, its peculiar modus vivendi and modus operandi. But expressing the archetype necessitates a philosopher, a philosophical genius for that matter, endowed with powerful intuition and engulfed by inspiration:

The power of the genius is always closely related to the power of the nation out of whose bosom it arose; needles to say, to its spiritual power. The genius becomes a representative of the spirit of his nation in that he can lend to the imaginings roaming around the nation shapes letting them be recognised as objects [emphasis - B. J.]. ${ }^{24}$

That is what the philosopher's task is about. Like the history of his nation serves as the "research material," capturing the nation's protoimage that manifests itself in the history is the key cognitive goal. So he collects and puts together its fragments scattered in the tales and pondered in history so that he can, out of the chaotic collection, "distil" and compose the purest form of Tradition.

What "method" is this new philosophy supposed to employ, to what cognitive powers is it supposed to refer? Above all, it is not to fret over the accusations of plunging into muddled, irrational "superstitions." In this context, Rzewuski perceptively observes (as if he was directly addressing contemporary sceptics and relativists):

Anyway, what is a prejudice, or a superstition? It is such a flexible and subjective thing that it is common for a prejudice or a superstition to pass for the truth, but it

${ }^{24}$ H. Rzewuski, Wędrówki umysłowe..., op. cit., p. 33. 
is even more common to encounter minds for whom the truth is a prejudice and a superstition. In this regard rationalists are by no means superior to ingenuous people, with whom geniuses, that is men of intuition and inspiration, are always more willing to agree than with the former ones [rationalists]. ${ }^{25}$

Superstitions have their origins - admittedly sometimes distant ones in intuition and inspiration, which are suitable "cognitive tools" of the new, national philosophy. Like Edmund Burke, ${ }^{26}$ Rzewuski regards superstitions as expressions of - so to speak - shared and communal wisdom, which always reaches further than purely rational wisdom. Thus, the perception of "prejudice" here comes almost as close as to match the hermeneutic meaning of "pre-judgement," that is "preconscious" cultural knowledge (or competence of cultural choice in line with the Tradition). The speculative reason, on the other hand, which is most fully expressed in the monumental constructs of German idealism, is capable of attaining no truth whatsoever, because its operation is merely a weird, though sometimes peculiarly spectacular, game of empty conceptual forms. As a matter of fact, no individual mind has the power to attain the truth (because such a mind knowingly breaks with the Tradition and the spirit of the nation):

An individual mind is always in error unless it reflects the universal mind specific to its nation - and this [universal] mind can preserve itself only in tales. A true philosopher is he who reflects on the tales of his nation and as he places them as an object before the nation, he lets the nation know its own strength [emphasis - B. J.]. Philosophy which deals with schoolish ergotism - which is presently undergoing a

25 H. Rzewuski, Wędrówki umysłowe..., op. cit., p. 57.

26 With regard to this, Edmund Burke observed as follows: "We are afraid to put men to live and trade each on his own private stock of reason, because we suspect that this stock in each man is small, and that the individuals would do better to avail themselves of the general bank and capital of nations and of ages. [...] Prejudice is of ready application in the emergency; it previously engages the mind in a steady course of wisdom and virtue and does not leave the man hesitating in the moment of decision skeptical, puzzled, and unresolved" (E. Burke, Reflections on the French Revolution \& Other Essays, J. M. Dent \& Sons Ltd., London 1910, p. 84). 
revival - and which does not refer to tales of any nation, but strives after some absolute, and which busies itself with analysing thought - in itself or in its forms - is but an eccentricity, and as such gives rise to nothing but logical aberrations. Philosophy is an idle tangle unless it is national or goes beyond the circle of revelation. Nations are guided by national tales, even though they are not endowed with self-knowledge as to the tales; even the privileged geniuses who know how to decipher these tales cannot fully comprehend them. A philosophy ready to take up studying tales would become a real and very useful science, as long as it does not get confined within the narrow bounds of a systema, and does not become a schoolish thing. For wherever a school becomes established, the spirit is gone, and left are only forms. ${ }^{27}$

In some other place, the author of Listopad is more specific:

Reasoning is not a creative force, but only a means of analysing some accidents of things. Intuition is humanity's sole creative force, because it places us in a closer relation to the eternal fire of creativity, strong intuition being inspiration. And since nothing resists intuition as firmly as reasoning, hence follows the obvious conclusion that human reasonings, that is philosophers, who are not - unlike poets and heroes - men of intuition, or inspiration, do not deserve any trust in all that requires sacrifice. ${ }^{28}$

There can be no doubt with regard to Rzewuski's view: purely rationalist philosophy is not and never will be an expression of the essentially transcendent Truth. For in the quest for it, it uses an unsuitable tool: reason "is merely a means of analysing some accidents of things," and not a power enabling attainment of the source of Life, the "eternal fire of creativity." Capturing the national idea can only be effected through the agency of a genius endowed with a particular power of inspiration and exceptional intuition, which acts as an internal force and source of the inspiration. The truth a genius-philosopher attains is always a specific truth, that is the truth of a given nation. Above the national truths stand

27 H. Rzewuski, Wędrówki umysłowe..., op. cit., pp. 19-20.

28 H. Rzewuski, Wędrówki umysłowe..., op. cit., p. 198. 
theological truths only, which are the only ones that can be deemed universal in the full sense of the word. These, however, cannot be attained by an individual reason either - after all they are revealed. They arise from revelation and to revelation they refer. Not only does reason fail to attain them, but in the process it can only obscure and distort them dismally.

\section{Conclusion}

Such is Rzewuski's outline of the plan for the Polish national philosophy, nay: Polish national metaphysics in its independence and complete distinction from the German, French as well as ancient philosophy. This metaphysics is supposed to seek and express the eternal spirit of Polishness, reveal its transcendently existent essence - after all, no one will do this for us, Polish thinkers. The Polish philosophy is tasked with enabling our nation to regain subjectivity, the shapes of which lie hidden in the ancient tradition of Sarmatian Poland. In conclusion, it almost feels tempting to invoke Rej's famous passage that "Poles are no Anserinae - they have a language of their own." But of course it is not about the obvious existence of a natural mother tongue, but about the language of expression in which - heedless of "sundry foreign nations" and their possible influence - that which is Polish and the uniquely Polish form of spiritual and social being will be conveyed.

Today, this concept might seem a trifle anachronistic, and yet quaintly fanciful - at least for the degree to which such deliberations are suffused with theological elements, which today is hardly acceptable in the scientific and philosophical discourse - but the message is straightforward and, in my opinion, still largely relevant. This is to mean that a nation is an indispensable being that cannot be reduced to "humanity," or even "Europeanness" - it has always been like this and needs to continue that way forever and ever, because nations are creations "descending from above," non-relative, Divine, perpetually enlivened by the transcendent breath. Thus, attempts aimed at their uniformisation are both in defiance of God and (for those who do not believe in Him) contrary to Nature and History. A philosophy of a given nation is supposed to convey its 
specificity and uniqueness, its distinctive spiritual and moral system, which contributes to the wealth of the world.

Still, one might regard this concept as highly exaggerated and romantically affected - one that could only be a product of an overly agitated imagination. Well, that may be true. But let us remember that eventually any change is originated in imagination. Sometimes it just stays there, but at other times it begins to "spill over" into the empirical world as well - after all it is from imagination that the world of men emerges. And since with God resurrection of a single man is not impossible, then resurrection of a nation, with all its specificity and greatness, is not impossible either - such a thought appears to pervade Rzewuski's philosophical deliberations, which are also profoundly religious in their essence.

\section{Abstract}

The purpose of this article is to present original philosophical concept by Henryk Rzewuski. This nineteenth century Polish thinker was (and still is) extremely controversial person, accused of national "apostasy" for the Tsarist Russia and the spread of beliefs about the irrevocable end of the Polish state. In this text reveals the complexity and ambivalence Rzewuskiego attitude towards the Polish cause. This philosopher believed that indeed the Polish state will not be standing free himself from the Russian political sovereignty. At the same time, however, was an ardent supporter of building the Polish national philosophy, which would illustrate Polishness and develop in the sphere of the ideal and spiritual. Polish history has to be - within its concept - the material from which the philosopher sees that these thoughts and ideas around which crytallized Polish spirit, and that reflect the basic idea of moral. The spirit of the nation and its moral idea meet, according to this philosopher, the functions analogous to that of the soul to the body is a condition of life and the unity of its geopolitical "body."

\section{Keywords}

The idea of the nation, national philosophy, individual intellect, collective intellect, intuition, inspiration, history, God's revelation, genius-philosopher 


\section{Bibliography}

Burke E., O duchu i naturze rewolucji, trans. A. Wincewicz-Price, Kraków 2012.

Merta T., Nieodzowność konserwatyzmu. Pisma wybrane, Warszawa 2012.

Węgrzyn I., Henryk Rzewuski wobec Rosji i idei słowiańskiej, [in:] Między realizmem a apostazją narodową. Koncepcje prorosyjskie w polskiej myśli politycznej, Kraków 2015, pp. 75-97.

Rzewuski H., Cywilizacja i religia, ed. A. Wielomski, Biała Podlaska 2009.

Rzewuski H., Mieszaniny obyczajowe przez Jarosza Bejłę, vol. 1, Wilno 1841.

Rzewuski H., Pamiątki Soplicy, Poznań 2014.

Rzewuski H., Wędrówki umystowe. Mieszaniny obyczajowe, Kraków 2010.

Tarnowski S., Henryk Rzewuski. Z odczytów publicznych odbytych we Lwowie w roku 1887, Lwów 1887.

Węgrzyn I., Henryk Rzewuski wobec Rosji i idei słowiańskiej, [in:] Między realizmem a apostazją narodową. Koncepcje prorosyjskie w polskiej myśli politycznej, Kraków 2015, pp. 75-97.

Wielomski A., Konserwatyzm. Główne idee, nurty i postacie, Warszawa 2007.

Wielomski A., Prawica w XX wieku, Radzymin 2013. 